GALENIKA Journal of Pharmacy Vol. 2 (1) : 43 - 48

ISSN : 2442-8744

March 2016

\title{
IDENTIFIKASI DRUG RELATED PROBLEMS (DRPs) PADA PASIEN ANAK GASTROENTERITIS AKUT DI INSTALASI RAWAT INAP RSU ANUTAPURA PALU
}

\section{IDENTIFICATION OF DRUG RELATED PROBLEMS (DRPs) IN PEDIATRIC PATIENTS OF ACUTE GASTROENTERITIS AT ANUTAPURA GENERAL HOSPITAL}

\author{
Arlinda $^{1}$, Alwiyah Mukaddas ${ }^{1}$, Ingrid Faustine ${ }^{1}$ \\ ${ }^{1}$ Jurusan Farmasi, Fakultas MIPA, Universitas Tadulako, Palu, Indonesia
}

Received 24 November 2015, Accepted 2 Januari 2016

\begin{abstract}
ABSTRAK
Gastroenteritis akut merupakan salah satu penyakit yang paling sering terjadi pada anak-anak dan salah satu penyebab kematian anak-anak di dunia, memiliki peluang besar terjadinya Drug Related Problems (DRPs). Penelitian ini bertujuan untuk mengetahui besarnya angka kejadian DRPs yang potensial terjadi pada pasien anak gastroenteritis akut di RSU Anutapura Palu, Sulawesi Tengah. Penelitian ini merupakan penelitian observasional yang dikerjakan secara prospektif dengan melihat data primer berupa hasil observasi pada pasien dan data sekunder berupa rekam medik pasien anak berumur 1 bulan - 14 tahun yang terdiagnosis gastroenteritis akut dengan atau tanpa dehidrasi yang dirawat inap. Data yang dianalisis disajikan secara deskriptif meliputi obat tanpa indikasi, obat salah, dosis obat kurang, dosis obat lebih, dan indikasi tanpa obat. Berdasarkan hasil penelitian, diperoleh total seluruh kasus DRPs adalah 115 kasus. Jenis DRPs yang paling banyak terjadi adalah obat tanpa indikasi, 56 kasus (48,7\%). Jenis DRPs lain berturut-turut adalah dosis obat kurang 26 kasus $(22,6 \%)$, indikasi tanpa obat 16 kasus $(14 \%)$, dosis obat lebih 15 kasus (13\%), dan obat salah 2 kasus $(1,7 \%)$.
\end{abstract}

Kata kunci : Drug Related Problems (DRPs), Gastroenteritis akut, RSU Anutapura

\begin{abstract}
Acute gastroenteritis, one of the most common disease in children and one of the causes of children's death in the world, has a great chance of the occurrence of Drug Related Problems (DRPs). This study aimed to determine the incidence of potential DRPs occurred in pediatric inpatients of acute gastroenteritis in Anutapura General Hospital, Palu, Central Sulawesi. This was a prospective observational study done by collecting primary data from the observation and secondary data from medical records of pediatric inpatients aged from 1 month to 14 years and diagnosed with acute gastroenteritis with or without dehydration. Data were then analyzed and descriptively presented including drug use without indication, wrong drug, drug dose too low, drug dose loo high, and untreated indication. The results showed that there were 115 cases of DRPs. The most DRPs found was drug use without indication as many as 56 cases (48.7\%), while the others successively were drug dose too low 26 cases (22.6\%), untreated indication 16 cases (14\%), drug dose too high 15 cases (13\%), and wrong drug 2 cases $(1.7 \%)$.
\end{abstract}

Keywords : Drug Related Problems (DRPs), Acute gastroenteritis, Anutapura General Hospital.

*Coresponding Author : Arlinda, indah.arlinda@yahoo.com(ph : +6282293043390) 


\section{PENDAHULUAN}

Gastroenteritis akut pada anak-anak didefinisikan sebagai penyakit yang pada mulanya terjadi diare dengan atau tanpa nyeri perut, demam, mual atau muntah (Catherine, 2012). Kasus ini paling sering terjadi di negaranegara berkembang dengan standar hidup yang rendah.

Salah satu penyebab utama kasus kematian anak-anak usia $<5$ tahun adalah diare. Pada tahun 2010, secara global distribusi diare sebanyak 761 ribu (10\%) dari 7,6 juta semua kasus kematian anak-anak usia $<5$ tahun. Distribusi diare di Asia Tenggara sebanyak 233 ribu (11\%) dari 2,1 juta kasus kematian anakanak usia $<5$ tahun (WHO, 2013).

Jumlah Kejadian Luar Biasa (KLB) diare yang ditemukan dan ditangani di Sulawesi Tengah pada tahun 2012 sebanyak 70.267 $(62.6 \%)$ dari 112.171 jumlah perkiraan penderita. Pada tahun 2013 jumlah KLB diare yang ditemukan dan ditangani sebanyak 59.430 $(109,3 \%)$ dari 54.349 jumlah penderita diare yang diperkirakan (Anonim, 2013).

Drug Related Problems (DRPs) merupakan bagian dari medication error atau kegagalan terapi. Penggunaan obat di dalam pengobatan suatu penyakit bertujuan untuk menyembuhkan, mencegah timbulnya gejala serta meningkatkan kualitas hidup pasien. Namun dalam proses maupun hasil terapi seringkali ditemukan masalah-masalah yang berkaitan dengan obat.

Hasil penelitian Erlina (2013) menunjukkan bahwa dari 47 pasien diare anak, terdapat 30 pasien $(63,82 \%)$ mengalami DRPs. Jenis DRPs yang terjadi adalah obat tanpa indikasi sebanyak 19 kasus $(26,69 \%)$, dosis obat kurang sebanyak 14 kasus $(21,88 \%)$, indikasi tanpa obat sebanyak 11 kasus $(17,19 \%)$, dosis obat lebih sebanyak 10 kasus $(15,63 \%)$, dan interaksi obat sebanyak 10 kasus $(15,63 \%)$ (Erlina, 2013).

Berdasarkan data yang diperoleh dari

Rumah Sakit Umum Anutapura Palu, gastroenteritis akut dalam dua tahun terakhir, masuk dalam 10 besar kategori penyakit terbanyak rawat inap pada semua kelompok umur, yaitu peringkat kedua pada tahun 2013 dan 2014 dengan jumlah kasus 525 dan 935 kasus. Selain itu, gastroenteritis akut menjadi penyebab kedua kematian pasien setelah Pneumonia.

Survei awal yang dilakukan terhadap rekam medik pasien gastroenteritis akut, ditemukan penggunaan antibiotik pada pengobatan pasien, sedangkan berdasarkan etiologi, $75-90 \%$ penyebabnya adalah virus. Menurut Pudjiadi, dkk (2011) antibiotik diberikan bila ada indikasi, misalnya disentri (diare berdarah) atau kolera.

Berdasarkan hal-hal yang diuraikan di atas, peneliti tertarik untuk melakukan penelitian secara prospektif mengenai identifikasi DRPs pada pasien anak gastroenteritis akut di Instalasi rawat inap RSU Anutapura Palu periode MaretJuni 2015.

\section{METODE PENELITIAN}

Jenis penelitian yang digunakan dalam penelitian ini merupakan penelitian observasional yang dikerjakan secara prospektif dengan melihat data primer berupa hasil observasi pada pasien anak gastroenteritis akut yang menjalani rawat inap di RSU Anutapura Palu dan juga melihat data sekunder berupa data rekam medik meliputi : nomor rekam medik, umur, berat badan, jenis kelamin, manifestasi klinik, derajat dehidrasi, obat-obat yang digunakan, parameter laboratorium, lama rawat inap, dan keadaan pulang pasien untuk memperoleh gambaran mengenai adanya DRPs yang meliputi : obat tanpa indikasi, obat salah, dosis obat kurang, dosis obat lebih, dan indikasi tanpa obat. Data yang dianalisis, disajikan secara deskriptif.

\section{HASIL DAN PEMBAHASAN}

Hasil

Tabel 1. Karakteristik Demografi pasien gastroenteritis akut yang dirawat inap di RSU Anutapura Palu Maret-Juni 2015

\begin{tabular}{|c|c|c|c|}
\hline No. & Karakteristik & $\begin{array}{c}\text { Jumbh Pasien } \\
(a=31)\end{array}$ & Persentase (\%) \\
\hline \multirow[t]{3}{*}{1.} & Umur & & \\
\hline & $1 \mathrm{bln}-5$ thri & 22 & $\pi$ \\
\hline & 6 thn -14 thn & 9 & 29 \\
\hline \multirow[t]{3}{*}{2.} & Jenis kelamin & & \\
\hline & Lald.takd & 21 & 68 \\
\hline & Perempuan & 10 & 32 \\
\hline
\end{tabular}


Tabel 2. Karakteristik klinik pasien gastroenteritis akut yang dirawat inap di RSU Anutapura Palu Maret-Juni 2015

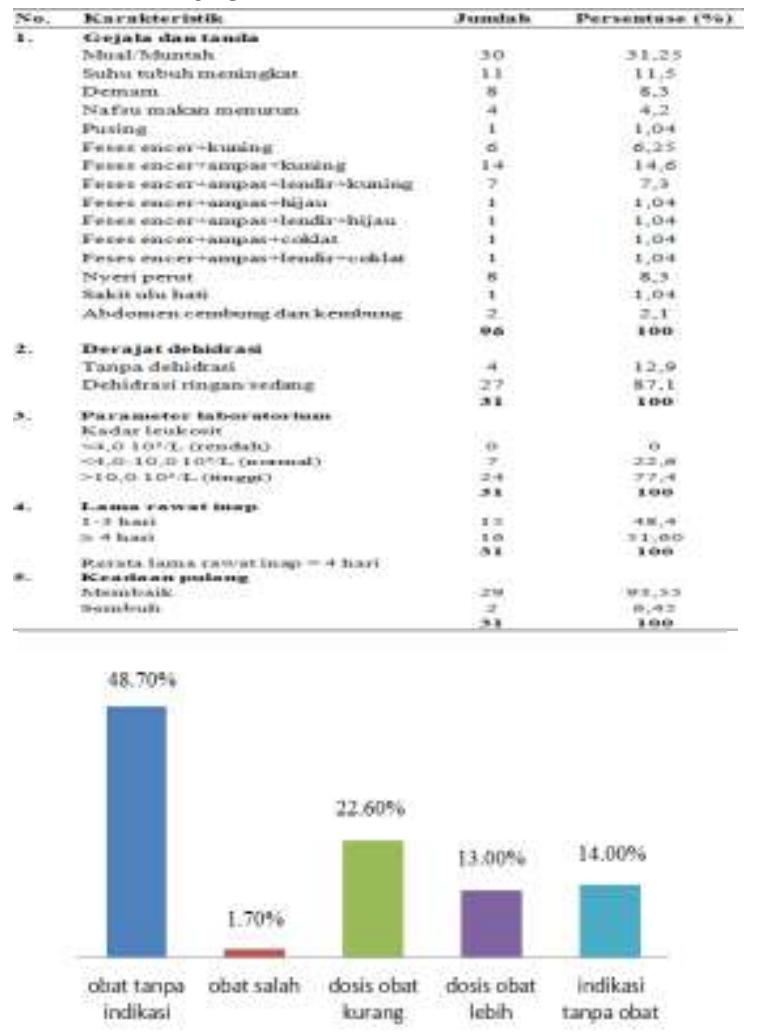

Gambar 1.DRPs pasien gastroenteritis akut yang dirawat inap di RSU Anutapura Palu Maret-Juni 2015.

Tabel 3. Distribusi penggunaan obat tanpa indikasi pada pasien gastroenteritis akut yang dirawat inap di RSU Anutapura Palu Maret-Juni 2015.

\begin{tabular}{lcccc}
\hline No. Golongan obat & Nama obat & $\begin{array}{c}\text { Total } \\
\text { kasas }\end{array}$ & $(\%)$ \\
\hline 1. & $\begin{array}{c}\text { Pirimetamin \& } \\
\text { derivat sulfonamid }\end{array}$ & $\begin{array}{c}\text { Trimetropim \& } \\
\text { sulfametoksazol }\end{array}$ & 11 & 9,6 \\
\hline 2. & Sefalosforin & Seftriakson & 24 & 20,9 \\
& generasi -3 & Sefotaksim & 2 & 1,6 \\
3. & Aminoglikosida & Gentamisin & 1 & 0,9 \\
4. & Nitrofuran & Nifuroksazid & 13 & 11,3 \\
\hline 5. & Kortikosteroid & Deksametason & 4 & 3,5 \\
\hline 6. & Benzodiazepin & Diazepam & 1 & 0,9 \\
\hline \multicolumn{7}{r}{ Total } & & 56 & $\mathbf{4 8 , 7}$ \\
\hline
\end{tabular}

Tabel 4. Distribusi penggunaan obat salah, dosis obat kurang, dosis obat lebih, indikasi tanpa obat pada pasien gastroenteritis akut yang dirawat inap di RSU Anutapura Palu MaretJuni 2015.

\begin{tabular}{|c|c|c|c|c|c|}
\hline No. & $\begin{array}{l}\text { Jentis } \\
\text { DRPs }\end{array}$ & Kelas terapi & Nama obat & $\begin{array}{l}\text { Jumbah } \\
\text { k:asus }\end{array}$ & $(\%)$ \\
\hline \multirow[t]{2}{*}{1.} & Obat salah & & & & 17 \\
\hline & & Antiemetik & Domperidon & 2 & \\
\hline \multirow[t]{7}{*}{2.} & $\begin{array}{c}\text { Dosis obat } \\
\text { Kamzang }\end{array}$ & & & & 22,6 \\
\hline & & Antipiretik & Asetaminofen & 6 & \\
\hline & & & Metampiron & 2 & \\
\hline & & Antibiotik: & Seftriakson & 9 & \\
\hline & & & Kotrimoksazol & 6 & \\
\hline & & & Sefotaksim & 2 & \\
\hline & & & Gentamisin & 1 & \\
\hline \multirow[t]{3}{*}{3.} & $\begin{array}{l}\text { Dosks obat } \\
\text { lebih }\end{array}$ & & & & 13 \\
\hline & & Antibiotik & Kotrimolssazol & 2 & \\
\hline & & Kortikosteroid & Deksamerason & 13 & \\
\hline \multirow[t]{2}{*}{ 4. } & $\begin{array}{l}\text { LuAlikasí } \\
\text { tampa obat }\end{array}$ & & & & 14 \\
\hline & & $\begin{array}{c}\text { Cairan } \\
\text { rehidrasi oral }\end{array}$ & Oralit & 16 & \\
\hline
\end{tabular}

\section{Pembahasan}

Pengelompokkan pasien berdasarkan umur dilakukan untuk mengetahui pada rentang umur berapa kasus gastroenteritis akut banyak terjadi. Pada penelitian ini, diperoleh pasien dengan umur 1 bulan -5 tahun adalah yang paling banyak terdiagnosa gastroenteritis akut (71\%) (tabel 1). Hasil ini sejalan dengan penelitian sebelumnya oleh Erlina (2013) memperoleh hasil sebanyak $78,72 \%$ pasien berumur 1 bulan - 5 tahun yang terdiagnosa gastroenteritis akut.

Berdasarkan hasil penelitian, diperoleh jumlah pasien laki-laki lebih banyak (68\%) daripada jumlah pasien perempuan (32\%). Hasil ini sejalan denganpenelitian yang dilakukan oleh Suri dan Kumar (2015) yang juga mendapatkan hasil penelitian yang menunjukkan jumlah pasien anak laki-laki $58,4 \%$ dan perempuan $41,6 \%$.

Gejala dan tanda yang dialami pasien saat masuk rumah sakit disajikan pada tabel 2. Gejala yang paling sering terjadi adalah mual/muntah $(31,25 \%)$. Suhu tubuh meningkat yaitu suhu pasien lebih dari $37,4^{0} \mathrm{C}$ (Lolita,dkk, 2014) sebesar $11,5 \%$, sedangkan demam adalah suhu pasien $>37,8^{\circ} \mathrm{C}$ (Fuadi, 2010) sebesar 8,3\% yang diukur pada aksila. Persentase karakteristik feses pada pasien yang terbesar adalah encer, berampas dan berwarna kuning sebesar 14,6\% 
yang terjadi pada 14 pasien, diikuti 7,3\% pasien dengan feses encer, berampas, berlendir, dan berwarna kuning yang terjadi pada 7 pasien, dan 6 pasien $(6,25 \%)$ dengan feses encer dan berwarna kuning. Gejala lainnya yang dialami pasien adalah nafsu makan menurun, pusing, nyeri perut, nyeri ulu hati, serta abdomen cembung dan kembung.

Hasil penelitian menunjukkan persentase pasien gastroenteritis akut tanpa dehidrasi lebih besar $(87,1 \%)$ daripada pasien yang terdiagnosa gastroenteritis akut dengan dehidrasi ringan/sedang $(12,9 \%)$.

Sebanyak $81 \%$ pasien yang mengalami peningkatan kadar leukosit saat masuk rumah sakit, dilihat dari hasil pemeriksaan darah lengkap pasien.

Rata-rata pasien dirawat selama 4 hari di rumah sakit. Hasil ini sejalan dengan Penelitian yang dilakukan oleh Sari (2009), yang memperoleh hasil pasien terbanyak adalah pasien dengan lama rawat inap 4 hari $(55 \%)$. Menurut SPM RS Anutapura Palu bahwa masa pemulihan gastroenteritis adalah 5-7 hari.

\section{Drug Related Problems (DRPs)}

Pada penelitian ini, terdapat 5 kategori DRPs yang dianalisis meliputi penggunaan obat tanpa indikasi, obat salah, dosis obat kurang, dosis obat lebih, dan indikasi tanpa obat yang persentasenya disajikan dalam bentuk diagram pada gambar 1 .

\section{Obat tanpa indikasi}

Tabel 3 menunjukkan distribusi penggunaan obat tanpa indikasi yang ditemukan pada pasien gastroenteritis akut yaitu antibiotik, kortikosteroid, antipiretik dan antikonvulsan. Berdasarkan data yang diperoleh selama penelitian, sebanyak 29 pasien $(96 \%)$ menerima terapi antibiotik. Menurut klinisi, terapi antibiotik diberikan dengan melihat adanya demam, kadar leukosit dari hasil pemeriksaan darah lengkap, serta adanya lendir pada feses dan berwarna hijau.

Demam tidak secara spesifik menunjukkan adanya infeksi bakteri karena infeksi virus pun juga dapat menyebabkan demam, selain itu demam juga bukan pertanda dan dibutuhkannya terapi antibiotik (Sari, 2009). Jika dilihat dari hasil pemeriksaan darah lengkap pasien, dari 29 pasien yang menerima terapi antibiotik, ditemukan 7 pasien yang memiliki kadar leukosit yang tidak melebihi kadar normal (4.0 $\left.10^{3} / \mathrm{L}-10.010^{3} / \mathrm{L}\right)$. Pada penelitian ini karakteristik feses pasien berbeda-beda (tabel 2). Menurut Gray dkk (1979) dalam P.0 Asnil dkk (2003), konsistensi feses pada pasien gastroenteritis akut yang disebabkan oleh rotavirus adalah encer dan jarang terdapat lendir serta warna feses berwarna hijau-kuning, dan tidak tedapat leukosit. Jika dilihat dari karakteristik feses pasien, pasien dengan feses encer, berampas, dan berwarna kuning yang berjumlah 14 pasien, dan pasien dengan feses encer tidak berampas dan berwarna kuning sebanyak 6 pasien, serta pasien dengan feses encer, berampas dan berwarna kuning-kehijauan sebanyak 1 orang, dapat dikategorikan sebagai gastroenteritis akut yang disebabkan oleh rotavirus.

Menurut Tjandrawinata dan Noviarni (2009) Leukosit feses bukan prediksi yang akurat bagi respon terapi terhadap antibiotik. Terapi antibiotik rutin tidak direkomendasikan pada gastroenteritis akut karena terbukti tidak efektif, Antibiotik diberikan hanya jika terdapat tanda-tanda infeksi baik infeksi intestinal maupun ekstra-intestinal (Pudjiadi dkk, 2011). Penggunaan antibiotik yang berlebihan dapat menyebabkan pertumbuhan bakteri-bakteri yang resisten, kejadian efek samping yang dapat membahayakan pasien dan menambah biaya pengobatan pasien. Gastroenteritis akut disebabkan oleh virus di hampir 99\% kasus, diikuti oleh infeksi bakteri dan kemudian protozoa (Heinz Peter, 2008). Oleh karena itu, penggunaan antibiotik pada penelitian dikategorikan sebagai DRP obat tanpa indikasi.

Penggunaan kortikosteroid dalam hal ini deksametason pada kasus yang ditemukan dikategorikan sebagai obat tanpa indikasi karena tidak ditemukannya indikasi apapun untuk diberikan kortikosteroid. Menurut Wells (2015), deksametason dapat diberikan untuk mengurangi demam karena membantu efektifitas dari antipiretik. Namun pada penelitian ini, dari 13 pasien yang menerima deksametason, 4 pasien menerima terapi deksametason sedangkan suhu tubuh berturut-turut adalah $36,3^{\circ} \mathrm{C}, 36^{\circ} \mathrm{C}, 36,2^{\circ} \mathrm{C}$, dan $36,9^{\circ} \mathrm{C}$. Pemberian antipiretik pada pasien 
menurut klinisi di rumah sakit adalah hanya pada saat suhu pasien $>37,5^{\circ} \mathrm{C}$.

Pada penelitian ini salah satu pasien juga menerima terapi diazepam sebagai antikonvulsan. Menurut Deliana (2002), diazepam merupakan pilihan utama untuk pengobatan kejang demam fase akut karena mempunyai masa kerja yang singkat. Kejang demam adalah bangkitan kejang yang terjadi pada kenaikan suhu tubuh (suhu rektal lebih dari $38^{\circ} \mathrm{C}$ ) akibat suatu proses ekstra kranial (Wardhani, 2013). Namun pada penelitian ini pasien tidak mengalami kejang, dengan suhu tubuh $37,5^{\circ} \mathrm{C}$, sehingga pemberian diazepam pada penelitian ini dikategorikan sebagai obat tanpa indikasi.

\section{Obat salah}

Antiemetik tidak termasuk rejimen pengobatan gastroenteritis akut pada anak-anak menurut pedoman standar WHO, akan tetapi oleh sebab tertentu seperti kekhawatiran keluarga pasien, klinisi biasanya memberikan antiemetik jika pasien mengalami muntah. Hasil studi yang dilakukan di Italia oleh Albano (2006) menemukan bahwa semua dokter anak meresepkan domperidone. Namun, meskipun domperidon memiliki profil efek samping yang baik, tidak direkomendasikan untuk pengobatan muntah pada gastroenteritis akut pada anak umur $<1$ tahun (Albano, et al, 2006).

\section{Dosis obat kurang}

Dalam penelitian ini, ditemukan golongan obat yang paling sering diberikan dengan dosis kurang adalah golongan antibiotik $(15,6 \%)$ dari $22,6 \%$ distribusi obat dengan dosis kurang (tabel 4). Selain ditemukan kurangnya dosis, juga terdapat penyebab DRPs lain pada kategori dosis obat kurang ini, yaitu frekuensi pemberian obat yang tidak tepat pada antibiotik Sefotaksim dan Gentamisin.

Sefotaksim (Cefotaxime) adalah golongan antibiotik sefalosforin generasi ketiga, yang dosis penggunaannya menurut buku acuan pediatric dosage handbook untuk bayi dan anak umur 1 bulan - 12 tahun dengan berat badan $<50 \mathrm{~kg}$ yaitu 100-200 mg/kgBB/hari dibagi setiap 6-8 jam. Pada kasus ini, pemberian injeksi sefotaksim pada 2 pasien berturut-turut adalah $150 \mathrm{mg} / 12 \mathrm{jam} ; 400 \mathrm{mg} / 12 \mathrm{jam}$. Dosis yang benar sesuai dengan berat badan pasien adalah berturut-turut $233 \mathrm{mg} / 8 \mathrm{jam}$; $483 \mathrm{mg} / 8 \mathrm{jam}$.

Gentamisin (Gentamicin) adalah golongan antibiotik aminoglikosida. Ditemukan satu pasien dalam penelitian ini yang menerima terapi dengan dosis obat frekuensi tidak tepat yaitu $20 \mathrm{mg} / 12 \mathrm{jam}$. Dosis gentamisin menurut buku acuan pediatric dosage handbook adalah 2$2,5 \mathrm{mg} / \mathrm{kgBB}$ tiap 8 jam, dan dosis yangbenar sesuai dengan berat badan pasien adalah $17,5 \mathrm{mg} / 8 \mathrm{jam}$.

\section{Dosis obat lebih}

Berdasarkan penelitian yang telah dilakukan, ditemukan 15 kasus (13\%) dosis obat lebih yang diberikan pada pasien anak gastroenteritis, dengan persentase penyebab kejadian DRPs kategori dosis lebih adalah golongan kortikosteroid yakni deksametason $(11,3 \%)$ dapat dilihat pada tabel 4.

\section{Indikasi tanpa obat}

Berdasarkan analisis data hasil penelitian, ditemukan 16 pasien (14\%) yang tidak menerima terapi sesuai dengan kondisi medisnya yaitu pemberian cairan rehidrasi oral (tabel 4).

Pengobatan paling utama pada gastroenteritis adalah dengan mengganti cairan tubuh yang hilang. Oralit diberikan untuk mengganti cairan dan elektrolit dan cairan tubuh yang terbuang. Untuk mencegah dehidrasi dibutuhkan garam elektrolit untuk mempertahankan keseimbangan elektrolit dalam tubuh (Erlina, 2013). Data yang diperoleh selama penelitian, semua sampel yang masuk ke UGD langsung diberikan cairan intravena. Menurut SPM RSU Anutapura Palu, pemberian cairan intravena diberikan pada pasien dengan dehidrasi berat.

WHO, European Society of Pediatric Gastroenterology Hepatology and Nutrition, dan US Centers for Disease Control and Prevention, merekomendasikan bahwa, tanpa adanya tanda-tanda dehidrasi, terapi rehidrasi oral harus diberikan (Kita et al, 2015).

\section{DAFTAR PUSTAKA}

Albano Fabio, Eugenia B., Maria I.S., Giulio De M. (2006). Antiemetic For Children With Gastroenteritis: Off Label But Still 
On In Clinical Practice, Pediatric Gastroenterology and Nutrition 43: 402404. Italy.

Anonim. (2013). Profil Kesehatan Provinsi Sulawesi Tengah tahun 2013, Dinkes Sulteng. Palu.

Asnil, dkk. (2003). Gastroenterologi Anak Praktis, Balai Penerbit FK UI, Jakarta.

Catherine, AC., \& Zahra, A. (2012). Gastroenteritis in children Part I and II, 85(11), American Family Physician.

Deliana, Melda. (2002). Tatalaksana Kejang Demam Pada Anak, Sari Pediatri, 4(2), 59-62.

Erlina, U. (2013). Identifikasi Drug Related Problems (DRPs) pada pasien anak diare di Instalasi Rawat Inap RSUP H. Adam malik Medan tahun 2011, Skripsi Fakultas Farmasi USU, Medan.

Fuadi, Bahtera Tjipta \& Wijayahadi N. (2010). Faktor Risiko Bangkitan Kejang demam Pada Anak, Sari Pediatri, 12(3).

Heinz, Peter, 2008, Management of Acute Gastroenteritis in Children, Pediatrics and Child Health, 18(10), 453-457.

Kita., Fumiyo., et al. (2015). Domperidone With ORT in the Treatment of Pediatric Acute Gastroenteritis In Japan : A Multicenter, Randomized Controlled Trial, Asia-Pasific Journal of Public Health, 27(2).

Lolita., dkk. (2014). Rujukan Cepat Obat Tanpa Resep Untuk Praktisi, EGC, Jakarta.

Lolopayung, M. (2013). Evaluasi Penggunaan Kombinasi Zink dan Probiotik pada Penanganan Pasien Diare Anak di Instalasi Rawat Inap RSUD Undata Palu Tahun 2013. Skripsi Prodi Farmasi Universitas Tadulako, Palu.
Pudjiadi, A.H., Handryastuti, S., Idris, N.S., Gandaputra, E.P., Harmoniati, E.D. (2011). Pedoman Pelayanan Medis Ikatan Dokter Anak Indonesia edisi II, Badan Penerbit IDAI.

Sari, Rossa T. (2009). Analisis Drug Related Problems Pola Pengobatan Gastroenteritis Akut Pada Pasien Anak Di ruang rawat inap RSUD Jombang Periode Januari-Desember Tahun 2006, Tesis Universitas Surabaya, Surabaya.

Taketomo., Carol, K., Jane, H., Hodding, Donna, M., Kraus. (2010). Pediatric Dosage Handbook, 17th Edition, Lexi Comp's, USA.

Tjandrawinata, \& Noviarny, (2009). Probiotics, Medicinus Scientific Journal of Pharmaceutical Development and Medical Aplication, 22(3).

Suri, S., \& Kumar, D. (2015). Diarrhoeal Diseases and its Associated Factors Among Children 1-5 Years of Age in a Rural of Jammu, The Health Agenda, 3, 82-87.

Wardhani, AK. (2013). Kejang Demam Sederhana Pada Anak Usia Satu tahun, Medula, 1(1).

Wells, Barbara, G., Joseph, T., DiPiro., Terry, L., Schwinghammer, Cecily, V., DiPiro. (2015). Pharmacotherapy a pathophysiologic approach, Ninenth edition, McGraw-Hill Education, New York.

WHO. (2013). World Health Statistik 2013. 